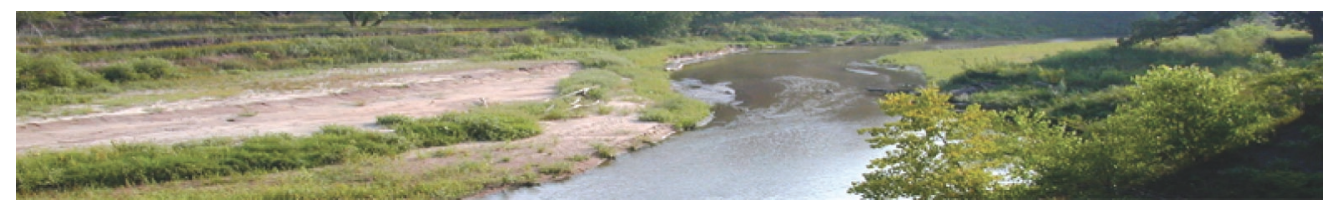

\title{
Maple Creek Watershed Selected for a National Water-Quality Study
}

The U.S. Geological Survey (USGS) is studying five watersheds across the Nation to better understand how natural factors and agricultural management practices (AMPs) affect the transport of water and chemicals. Natural factors include climate and landscape (soil type, topography, geology), and AMPs include practices related to tillage, irrigation, and chemical application. The study approach is similar in each watershed so that we can compare and contrast the results and more accurately predict conditions in other agricultural settings.

\section{Study objectives}

- Understand the links between the sources of water and agricultural chemicals (nutrients and pesticides) and their behavior and transport through the environment

- Predict the behavior and transport of water and agricultural chemicals in other agricultural areas not being studied

- Evaluate what the study results mean for management of water and water quality in a variety of agricultural settings

\section{We appreciate your help}

We are working with local growers and land owners to gain access to study sites. We also need information about the watershed and about current as well as historical agricultural management practices-past practices also affect concentrations of agricultural chemicals in ground and surface water.

We will report the findings of the study in public meetings and in publications. These findings will provide information that will be useful for improving agricultural management locally and nationally, and will guide future studies in other watersheds.

\section{Why study the Maple Creek watershed?}

Maple Creek and the other four watersheds represent nationally important agricultural settings (chemical use, crops, and AMPs) and natural settings (climate, geology, topography, and soils). Maple Creek, which is part of the Elkhorn River watershed, is representative of corn and soybean row cropping in the upper Great Plains.

Other features of the watershed that are relevant to this study:

- Use of agricultural chemicals: Chemicals used include herbicides such as atrazine, alachlor, acetochlor, metolachlor, and glyphosate; and fertilizers, both organic and inorganic.

- Distinct natural setting: The rolling upland hills and a permeable surficial aquifer overlain by less permeable glacial till allow water and chemicals to move overland to streams and into Maple Creek. The relatively flat valley bottom lands and wooded riparian zones along Maple Creek reduce runoff from fields.

- Variety of agricultural management practices: AMPs include tillage and no-tillage; use of central pivot irrigation; maintenance of grassy waterways and riparian buffer zones; construction of storm retention ponds.

- Water-quality issues: Herbicides and nutrients have been frequently detected in eastern Nebraska surface and ground water, including in drinking-water wells (findings of USGS studies since the 1990s).

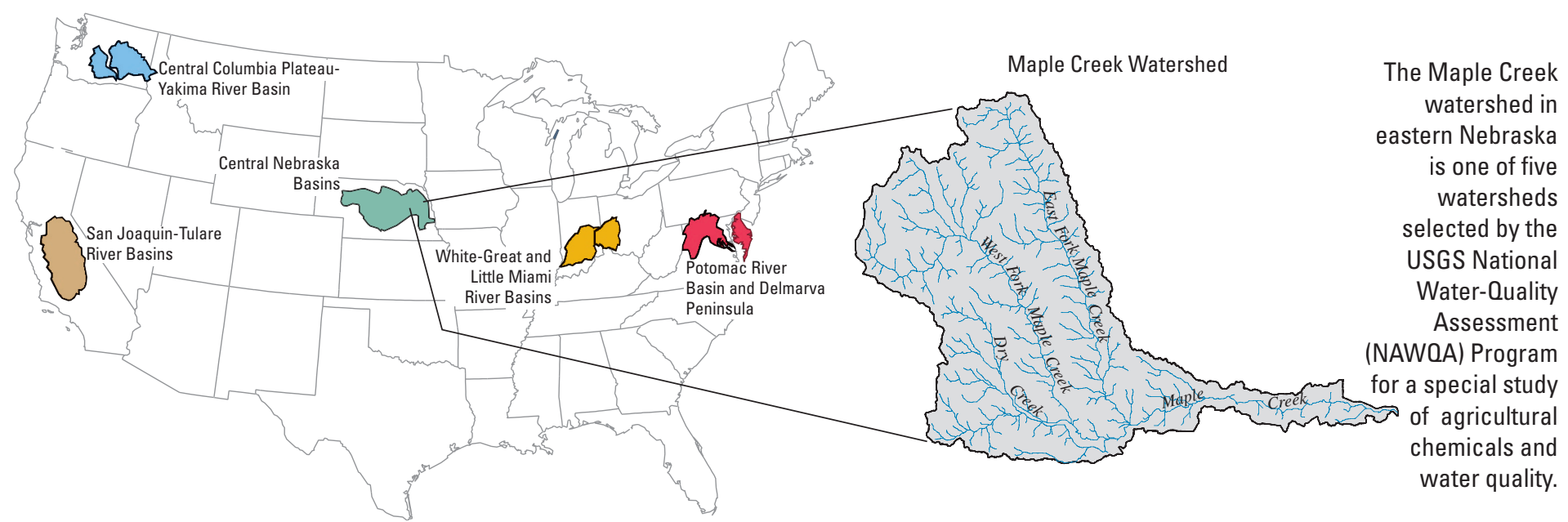


At a typical study site, several methods are used to collect water and chemical samples from the air, soil, surface water, and ground water.

After being applied to the land surface, agricultural chemicals can move upward into the atmosphere, downward through the soil to shallow ground water and underlying aquifers, eventually discharging to streams, or run off across the land into streams, eventually moving downstream to reservoirs and coastal waters. This process can take days, weeks, or even decades if water moves underground through the ground-water system.

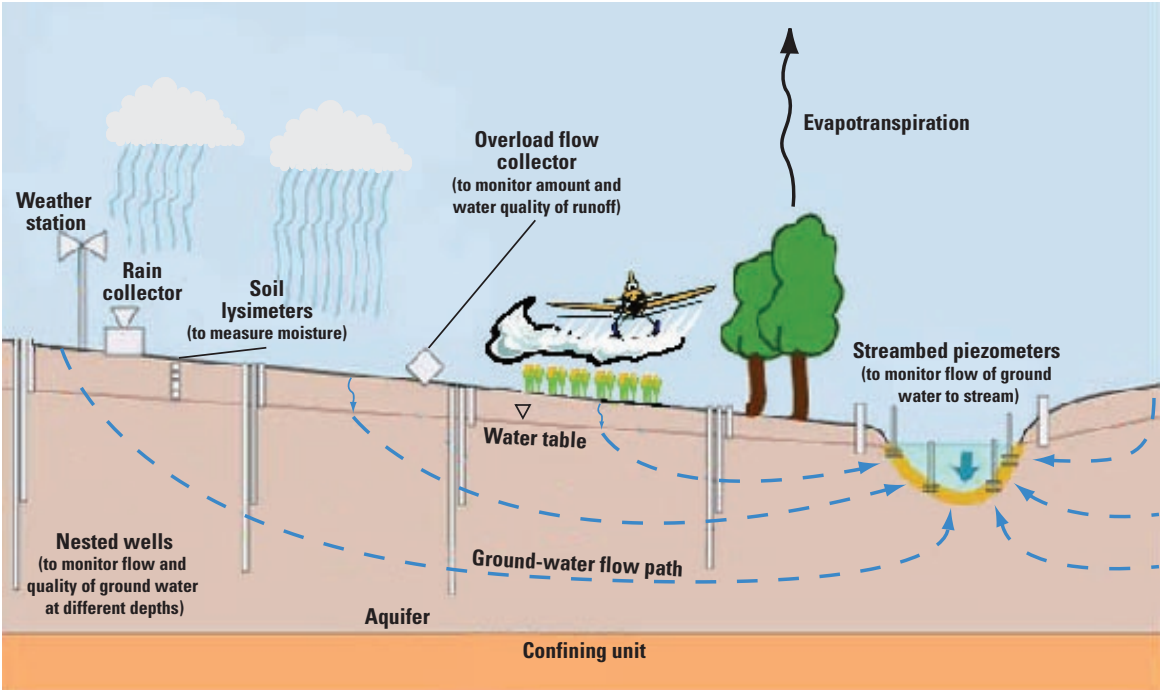

Data Collection in the Maple Creek Watershed, 2003-2004

\begin{tabular}{ll}
\hline \multicolumn{1}{c}{ What kind of data } & \multicolumn{1}{c}{ Why the data are collected } \\
\hline $\begin{array}{l}\text { Meteorological data, including rainfall, } \\
\text { wind speed, solar radiation, and air tem- } \\
\text { perature. Soil temperature and moisture }\end{array}$ & $\begin{array}{l}\text { To determine amount of precipitation and how } \\
\text { much water from land surface reaches the water } \\
\text { table, how much is lost to evapotranspiration }\end{array}$ \\
$\begin{array}{ll}\text { Amount of streamflow at Maple Creek } \\
\text { near Nickerson, NE, gaging station and } \\
\text { at unnamed tributary to the South Fork of }\end{array}$ & $\begin{array}{l}\text { To interpret water-quality data correctly } \\
\text { (the amount of water in streams affects chemical } \\
\text { concentrations) }\end{array}$
\end{tabular}

Dry Creek near Schuyler, NE

Quality of stream water, runoff water, rain water ${ }^{1}$

Ground-water levels in wells

Quality of ground water, soil water, and shallow water in and around streambed/ riparian $z^{1}$

Quality of sediment in streambed and soils in agricultural fields ${ }^{1}$
To quantify the transport and behavior of natural and agricultural chemicals

To determine direction of ground-water flow, which affects transport of chemicals

To quantify the transport and behavior of natural and agricultural chemicals
Continuously since 1951 at Maple Creek (real-time data available at http://waterdata.usgs.gov/ne/nwis/ uv?site_no=06800000 ). Since May 2003 at unnamed tributary to the South Fork of Dry Creek

Several times a year $(>14$ samples) for 2 years, with intensive sampling during application season

At least quarterly in some wells, continuously in others for at least 1 year

At least quarterly for 1 year

${ }^{1}$ In this study, water-quality and sediment-quality data include concentrations of nutrients (nitrogen and phosphorous), pesticides and pesticide breakdown products, and natural constituents and properties, including major ions (calcium, magnesium, chloride, etc.), organic carbon, dissolved oxygen, and temperature.

\section{We would like to thank}

University of Nebraska-Lincoln, Conservation and Survey Division

\section{For more information}

Jason Vogel, Lead Scientist, Maple Creek study

(402) 437-5129, jrvogel@usgs.gov

Paul Capel, Team Leader, National study

(612) 625-3082, capel@usgs.gov

NAWQA Program http://water.usgs.gov/nawqa

\section{Publication}

Frenzel, S.A., and others, 1998, Water Quality in the Central Nebraska Basins, 1992-95, U.S. Geological Survey Circular 1163. 